\title{
Chemical Characterization and in Vitro Antitumor Activity of the Essential Oils from the Leaves and Flowers of Callistemon viminalis
}

\author{
Christiane Maria de Oliveira1, Maria das Graças Cardoso ${ }^{1 *}$, \\ Marisa Ionta ${ }^{2}$, Marisi Gomes Soares ${ }^{3}$, Juliana de Andrade Santiago', \\ Guilherme Álvaro Ferreira da Silva ${ }^{2}$, Maria Luisa Teixeira ${ }^{1}$, \\ Danúbia Aparecida de Carvalho Selvati Rezende', Rafaela Vieira de Souza1, \\ Luana Isac Soares ${ }^{1}$, David Lee Nelson", Marcos Schleiden Sousa Carvalho ${ }^{5}$ \\ ${ }^{1}$ Department of Chemistry, Federal University of Lavras, Lavras, Brazil \\ ${ }^{2}$ Institute of Biomedical Sciences, Federal University of Alfenas, Alfenas, Brazil \\ ${ }^{3}$ Department of Chemistry, Federal University of Alfenas, Alfenas, Brazil \\ ${ }^{4}$ Federal University of Vales de Jequitinhonha e Mucuri, Diamantina, Brazil \\ ${ }^{5}$ Department of Agriculture, Federal University of Lavras, Lavras, Brazil \\ Email: ${ }^{*}$ mcardoso@dqi.ufla.br
}

Received 24 August 2015; accepted 26 October 2015; published 29 October 2015

Copyright (C) 2015 by authors and Scientific Research Publishing Inc.

This work is licensed under the Creative Commons Attribution International License (CC BY). http://creativecommons.org/licenses/by/4.0/

(c) $\underset{\mathrm{EY}}{\mathrm{E}}$ Open Access

\section{Abstract}

The objective of this study was to characterize and verify the in vitro antitumor activity of essential oils (EOs) extracted from the leaves and flowers of Callistemon viminalis. The EOs were extracted by hydrodistillation using a modified Clevenger apparatus. The identification and quantification of constituents were performed on a gas chromatograph coupled to a mass spectrometer and a gas chromatograph with a flame ionization detector. The antitumoral activity was evaluated by a colorimetric assay (MTS) using different cell lines derived from human tumors (breast, lung, glioblastoma, and melanoma). The major constituents of the EOs of leaves and flowers were similar, only quantitative differences being observed. The compounds 1,8-cineole, $\alpha$-pinene and $\alpha$-terpineol were found in concentrations of $50.4 \%, 25.8 \%$ and $8.7 \%$ in the EOs obtained from the leaves and $48.8 \%, 24.5 \%$ and $3.9 \%$ in the EOs obtained from the flowers, respectively. The cytotoxic activity of the EOs was observed only in melanoma cultures (HT144). Cultures treated for 48 $h$ with EOs from leaves and flowers $\left(200 \mu \mathrm{g} \cdot \mathrm{mL}^{-1}\right)$ reduced the viability by $40 \%$ and $25 \%$, respectively. Thus, the antiproliferative activity of the EO from leaves was more pronounced than the EO from flowers in cells derived from melanoma.

\footnotetext{
${ }^{*}$ Corresponding author.
}

How to cite this paper: de Oliveira, C.M., et al. (2015) Chemical Characterization and in Vitro Antitumor Activity of the Essential Oils from the Leaves and Flowers of Callistemon viminalis. American Journal of Plant Sciences, 6, $2664-2671$. 


\section{Keywords}

\section{Cancer, Volatile Oil, Escova-de-Garrafa (Bottle Brush)}

\section{Introduction}

Since ancient times, plants have provided a rich source of compounds with applications in the fields of medicine, pharmacy and biology. Molecules of plant origin, including alkaloids, saponins, triterpenes, glycosides and polyphenols, have shown promising antitumor activity in experimental models in vitro and in vivo [1]. Vinca alkaloids (vincristine and vinblastine), epipodophyllotoxin derivatives, camptothecin, etoposide and paclitaxel represent classic examples of compounds with therapeutic application in cancer [1]. However, the high toxicity of these compounds and the resistance commonly observed in some types of tumors have motivated the search for new therapeutic approaches.

Cancer is among the leading causes of mortality and morbidity in the world, and its incidence has increased because of multiple factors, including the increase in life expectancy of the population and changes in lifestyle. It is estimated that about 14 million new cases and 8.2 million deaths occurred in the world in 2012 [2]. According to the National Cancer Institute (INCA), it is estimated that about 580,000 new cases of cancer will be diagnosed in Brazil in 2015 [3], representing a major public health problem. Thus, the identification of new compounds with antiproliferative activity plays an important role in the prevention and treatment of cancer.

In recent years, essential oils (EOs) have been widely investigated for their various activities because they contain a wide variety of chemical components [4]-[6]. Studies have shown that many of the components in EOs may be useful in cancer therapy. In this context, this study sought to describe the chemical composition of the essential oils from the leaves and flowers of Callistemon viminalis and their antitumor activities against various cell lines of human cancer.

\section{Material and Methods}

\subsection{Collection, Identification and Extraction of the Essential Oils}

C. viminalis was collected in March 2014, in the morning, on the campus of the Federal University of Lavras (UFLA) in Lavras, MG, Brazil (21 $13^{\circ} \mathrm{S}$ latitude and $44^{\circ} 58^{\prime} \mathrm{W}$ longitude; average altitude, $915 \mathrm{~m}$ ) on a day with mild weather and no rainfall. The parts of the plant used separately for the extraction of essential oils were the leaves and the flowers. They were cleaned, weighed, and minced, and the essential oils were immediately extracted. A voucher specimen was deposited in the ESAL Herbarium in UFLA under the registration number 26,624 .

The essential oils from leaves and flowers were extracted in the Organic Chemistry Laboratory-Essential Oils of the Department of Chemistry, UFLA. The plant materials (300 g each) were subjected to hydrodistillation for 2 hours using a modified Clevenger apparatus [7]. After extraction, the oils were separated from the hidrolacts by centrifugation using a benchtop centrifuge with a horizontal crosspiece (Fanem Model 206 Baby ${ }^{\circledR I}$ BL) at $965.36 \mathrm{~g}$ for $5 \mathrm{~min}$. Subsequently, the essential oils were stored in amber containers under refrigeration [8].

To determine the moisture content for subsequent calculation of the yield of the oil present in the fresh plant, $5 \mathrm{~g}$ of the chopped plant material was extracted with $80 \mathrm{~mL}$ of cyclohexane, employing a Dean-Stark extractor. The moisture content was determined in triplicate according to the method described by Pimentel et al. [9].

\subsection{Identification and Quantification of Essential Oil Components}

Quantitative analysis and the identification of the constituents of the essential oils were accomplished at the Laboratory of Phytochemistry and Medicinal Chemistry (LFQM), Federal University of Alfenas (UNIFAL).

\subsubsection{Analysis by GC-FID and GC-MS}

The GC analyses were performed on a Hewlett-Packard 5890-Series II chromatograph (carrier gas, He) equipped with a FID detector, HP-5 capillary column (5\% diphenyl in 95\% of dimethylpolysiloxane-length, 30 $\mathrm{m}$, internal diameter, $0.32 \mathrm{~mm}$, film thickness, $0.25 \mathrm{~mm}$ ), an HP 7673 automatic injector (split 1:20) and an HP 
3396A electronic integrator. The oven temperature was programmed from $60^{\circ} \mathrm{C}-280^{\circ} \mathrm{C}$ with a heating rate of $3^{\circ} \mathrm{C} \mathrm{min}^{-1}$, and the temperature was maintained for $10 \mathrm{~min}$ at $280^{\circ} \mathrm{C}$. The temperatures of the injector and detector were maintained at $220^{\circ} \mathrm{C}$ and $280^{\circ} \mathrm{C}$, respectively. The concentrations of the components were calculated on the basis of the peak areas in the chromatograms in order of elution from the HP- 5 column. Analysis by GC-MS was performed on a Hewlett-Packard HP-6890 chromatograph (HP-5 column-5\% diphenyl in 95\% of dimethylpolysiloxane-length, $30 \mathrm{~m}$, internal diameter, $0.32 \mathrm{~mm}$, film thickness, $0.25 \mathrm{~mm}$, carrier gas, He) coupled to a Hewlett-Packard HP-5973 mass spectrometer (operating by electron impact, 70 ev) under the same temperature conditions described above.

The identification of the components was based on the comparison of their mass spectra with those of the spectrometer database (Wiley and NIST Libraries) and confirmed by determination of their Kovats indices, which were calculated relative to the retention times of a series of $\mathbf{n}$ alkanes [10].

\subsubsection{Analysis by $1 \mathrm{H}$ - and $13 \mathrm{C}-\mathrm{NMR}$}

1H- and 13C-NMR spectra were recorded at 500 and $125 \mathrm{Mhz}$, respectively, on a Bruker model DRX-500 spectrometer with the sample dissolved in CDCl3 containing 1\% TMS (Aldrich).

\subsection{In Vitro Evaluation of Anti-Tumor Activity}

\subsubsection{Cell Lines and Culture Conditions}

The tests were conducted on cell lines derived from human tumors (Table 1). Cell cultures were maintained in DMEM (Dulbecco's Modified Eagle's Medium; Sigma, CA, USA) supplemented with $10 \%$ fetal bovine serum (Vitrocell, Campinas, Brazil). The cultures were maintained under controlled atmosphere $\left(95 \%\right.$ air and 5\% $\left.\mathrm{CO}_{2}\right)$ in an incubator at $37^{\circ} \mathrm{C}$.

\subsubsection{Treatment Schedule}

Cells were seeded in 96 well plates at a density of $5 \times 103$ (U251MG and A549), $1 \times 104$ (HT144) or $2 \times 104$ (HepG2 and MCF7) cells/well. After adherence $(24 \mathrm{~h})$, the cells were treated for $48 \mathrm{~h}$ with EOs extracted from the leaves and flowers of $C$. viminalis. The oils were dissolved in DMSO to obtain the stock-solution (100 $\mathrm{mg} \cdot \mathrm{mL}^{-1}$ ).

Initially, essential oils were tested on the different cell lines derived from human tumors at a concentration of $50 \mu \mathrm{g} \cdot \mathrm{mL}^{-1}$ for observation of the activity profile. Subsequently, dose-response curves were constructed using the HT144 cell line and different concentrations of essential oil extracted from the leaves ( 5 to $200 \mu \mathrm{g} \cdot \mathrm{mL}^{-1}$ ). The final DMSO concentration did not exceed $0.5 \%(\mathrm{v} / \mathrm{v})$ and did not alter the cell viability that was determined by MTS.

\subsubsection{Cell Viability}

Cell viability was assessed by the colorimetric assay (MTS) using the Cell Titer 96TM kit from Promega ${ }^{\circledR}$. This assay is based on the conversion of 3-(4,5-dimethylthiazol-2-yl)-5-(3-carboxymethylphenyl)-2-(4-sulfophenyl2H-tetrazolium) bromide (MTS-yellow) to formazan (brown) by dehydrogenase enzymes present in the mitochondria of viable cells.

The production of formazan, a compound soluble in the culture medium that absorbs light at $490 \mathrm{~nm}$, is directly

Table 1. Cell lines derived from human tumors used in the in vitro assay of antiproliferative activity.

\begin{tabular}{cc}
\hline Code & Name \\
\hline A549 & lung adenocarcinoma \\
MCF7 & breast adenocarcinoma \\
HepG2 & liver carcinoma \\
U251MG & glioblastoma \\
HT144 & melanoma \\
\hline
\end{tabular}


proportional to the number of living cells [11]. Thus, this reaction occurs only with viable and metabolically active cells and provides a versatile and quantitative assay [12]. Viability was determined by comparing the absorbance values of the treated samples with the absorbance values obtained in control samples. The experiments were performed in triplicate and data were presented as the mean \pm standard deviation.

$$
\text { Cell viability } \%=\left(\mathrm{Abs}_{\text {sample }} \times 100\right) / \mathrm{Abs}_{\text {control }}
$$

\subsection{Statistical Analysis}

The ANOVA test and Tukey's post-test were applied. Differences were considered significant when the p value was less than $0.05(\mathrm{p}<0.05)$. The analysis was performed using the GraphPad Prism software (GraphPad Software, Inc., San Diego, CA, USA).

\section{Results and Discussion}

The same constituents were identified in the essential oils extracted from C. viminalis leaves and flowers, but in different percentages. Nineteen chemical compounds were identified in the essential oils from both the leaves and flowers. 1,8-cineole, $\alpha$-pinene and $\alpha$-terpineol were the major components at concentrations of $50.4 \%, 25.8 \%$ and $8.7 \%$ for the leaves and $48.8 \%, 24.5 \%$ and $3.9 \%$ for the flowers, respectively. The monoterpene 1,8 -cineole was identified as the major component in the essential oils from both the leaves (50.4\%) and the flowers (48.8\%) by GC-MS analysis of the crude oil in association with analysis by $1 \mathrm{H}$ and 13C-NMR, followed by comparison with literature data [13] [14].

Oyedeji et al. (2009) [15] identified 20 constituents in the essential oil from C. viminalis leaves collected in South Africa and reported 1,8-cineole (83.2\%), $\alpha$-pinene (6.4\%) and $\alpha$-terpineol (4.9\%) as the main components. Silva et al. (2010) [16] evaluated the chemical composition of the essential oil from C. viminalis collected in Brazil and identified 1,8-cineole (65\%), $\alpha$-pinene (12\%) and $\alpha$-terpineol (13\%) as the principal components.

Pires et al. (2013) [17] evaluated the chemical composition of the essential oils from C. viminalis leaves and flowers collected in Brazil, and observed that 1,8-cineole was the major component in the essential oil from fresh flowers and leaves $(70.43 \%$ and $42.39 \%$, respectively), followed by tricicleno ( $12.97 \%$ and $28.08 \%$, respectively) and $\alpha$-terpineol (6.56\% and 6.67\%). However, tricicleno was not found in the essential oils from the leaves and flowers in the current study.

The production of secondary metabolites of a species can be influenced by several factors, including the physiological demand of the plant (growth, defense and reproduction), as well as genetic and environmental factors (soil composition, rainfall and climate). Thus, minor quantitative and qualitative variations in the chemical composition of the EOs of $C$. viminalis may occur [18]-[20]. Nevertheless, most studies indicate that 1,8-cineole, $\alpha$-pinene and $\alpha$-terpineol are the principal components, so the results of this study corroborate those described in the literature.

The essential oils extracted from the leaves and flowers of $C$. viminalis were tested for in vitro antitumor activity. Initially, the different cell lines derived from human tumors were treated with EOs at a concentration of $50 \mu \mathrm{g} \cdot \mathrm{mL}^{-1}$. The results showed that EO extracted from C. viminalis flowers presented no antiproliferative activity against the cell lines tested, there being no significant reduction in cell viability in treated cultures compared to the control (Figure 1).

However, a 20\% reduction in viability was observed in cultures of melanoma (HT144) treated for $48 \mathrm{~h}$ with EO extracted from the leaves of $C$. viminalis (Figure 2).

On the basis of these results, the HT144 cell line was selected for further testing. The results showed that EOs exert a dose-dependent effect on the HT144 cells because the viability in treated cultures progressively decreased as the concentration of EOs increased (Figure 3 and Figure 4). The antiproliferative effect of the EO from the leaves was observed to be more active than that from the flowers. The viabilities of cultures treated for 48 hours with EOs from the leaves and flowers of $C$. viminalis at the concentration of $200 \mu \mathrm{g} \cdot \mathrm{mL}^{-1}$ decreased by about $40 \%$ and $25 \%$, respectively.

The lipophilic nature of the EOs allows them to easily cross cell membranes and reach the interior of the cells. The cytotoxic effects of several compounds may be related to damage or changes in cell membrane permeability. Thus, several studies have reported the potency of the constituents of EOs in the prevention and treatment of cancer [21]. Sobral et al. (2014) [22] showed, through studies performed in vitro and in vivo, that the antitumor 


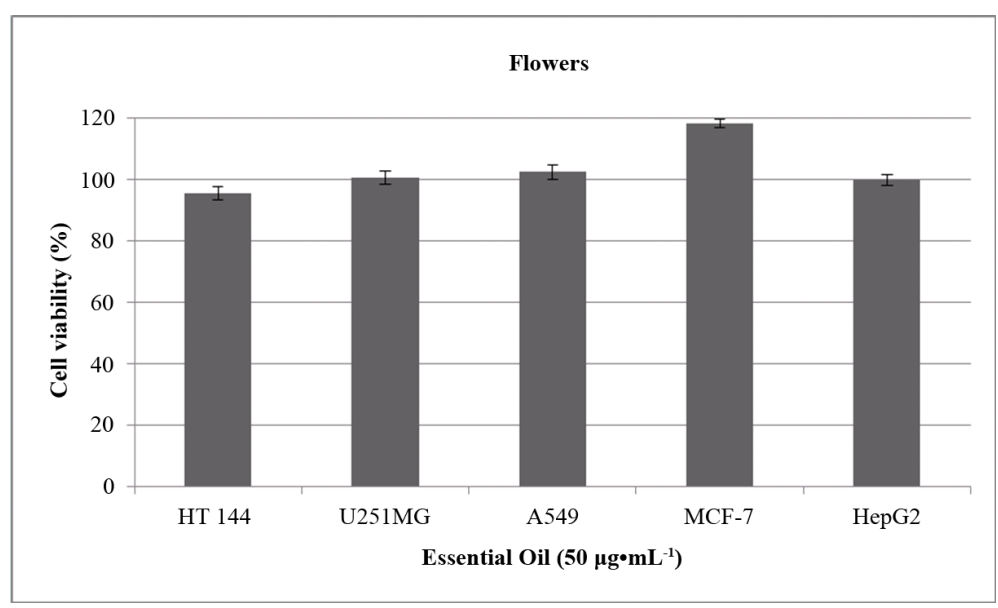

Figure 1. Cell viability (\%) determined by the MTS assay in cell cultures treated with the essential oil from $C$. viminalis flowers at a concentration of 50 $\mu \mathrm{g} \cdot \mathrm{mL}^{-1}$.

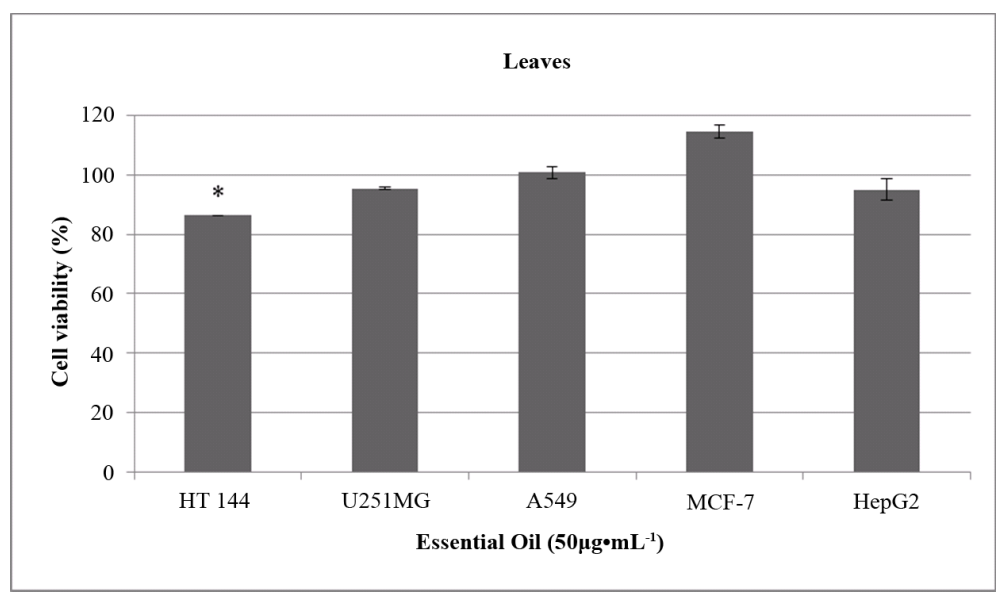

Figure 2. Cell viability (\%) determined by the MTS assay in cell cultures treated with the essential oil from $C$. viminalis leaves at a concentration of 50 $\mu \mathrm{g} \cdot \mathrm{mL}^{-1}$. $^{*}(\mathrm{p}<0.05)$.

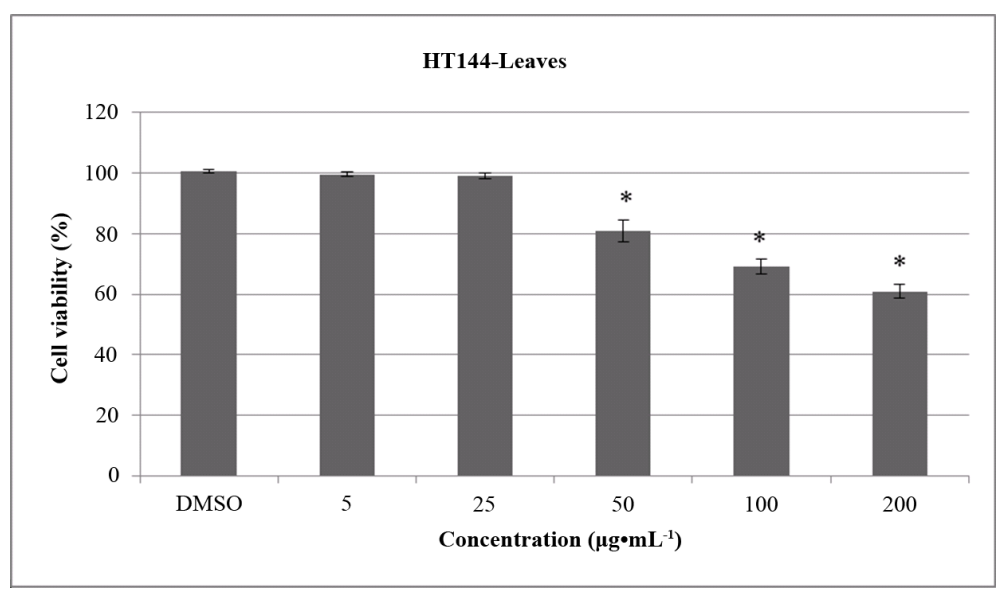

Figure 3. Cell viability (\%) determined by the MTS assay in HT144 cell cultures treated for $48 \mathrm{~h}$ with different concentrations of the essential oil from C. viminalis leaves. * $(\mathrm{p}<0.05)$. 


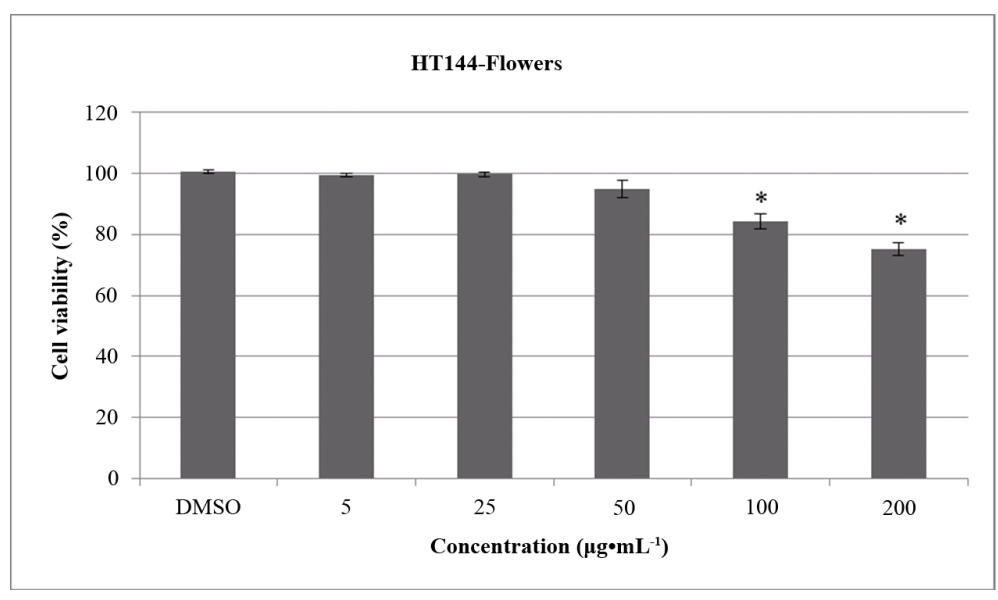

Figure 4. Cell viability (\%) determined by the MTS assay in HT144 cell cultures treated for $48 \mathrm{~h}$ with different concentrations of the essential oil from C. viminalis flowers. ${ }^{*}(\mathrm{p}<0.05)$.

activity of EOs of many species has been linked to the presence of monoterpenes, the class of compounds also found in C. viminalis oils.

The cytotoxicity of the essential oil extracted from Rosmarinus officinalis L. and its three main components [1,8-cineole (27.23\%), $\alpha$-pinene (19.43\%) and $\beta$-pinene (6.71\%)] was investigated in cell lines derived from human ovarian (SK-OV-3 and HO-8910) and liver (Bel-7402) cancers. The EO from $R$. officinalis exhibited a pronounced cytotoxicity to the three cell lines tested. The $\mathrm{IC}_{50}$ values were $0.025 ; 0.076$ and $0.13 \%$ o $(\mathrm{v} / \mathrm{v})$, respectively. The monoterpene 1,8-cineole, which is also the major compound found in essential oils from $C$. viminalis leaves and flowers, presented moderate cytotoxicity to those lines [23]. Moderate cytotoxicity of 1,8cineole and $\alpha$-terpineol, major constituents also found in this study, was observed in the HepG2 (liver carcinoma) and K-562 (leukemia) lines [24].

Lampronti, Saab and Gambari (2006) [25] showed that the EO from Satureja montana, whose main component is $\alpha$-terpineol, exhibited considerable cytotoxicity to K562 cells (human erythroleukemic). Hassan et al. (2010) [26] suggested that $\alpha$-terpineol inhibits tumor cell growth by a mechanism that involves inhibition of the NF-kB (nuclear factor kappa B). Jin et al. (2010) [27] showed that $\alpha$-pinene, also found in this study, triggered oxidative stress and related signaling pathways in the HepG2 and A549 tumor cells.

In the present study, it was shown that EOs from the leaves and flowers of $C$. viminalis exerted moderate cytotoxicity in the HT144 cell line. Considering that the melanoma is high lethal [3], the results obtained in the present study are very promising and further studies will be performed to verify whether the cytotoxic activity previously observed is related to pro-apoptotic potential of the essential oils. Reduction of cell viability in HT144 cultures may be related to the presence of 1,8 cineole, $\alpha$-pinene and $\alpha$-terpineol, but considering that essential oils have a complex chemical composition, it is possible that the reduction in viability was the result of synergistic action of the constituents found in the EOs [28]. The monoterpenes are considered to be the active compounds, and, therefore, additional studies should be conducted to further investigate the relationship of monoterpenes with antiproliferative or cytotoxic effects of EOs on melanoma cells.

\section{Conclusions}

The principal constituints found in the essential oils from Callistemon viminalis were 1,8 cineole, $\alpha$-pinene and $\alpha$-terpineol in the concentrations of $50.4 \%, 25.8 \%$ and $8.7 \%$ for the leaves; and $48.8 \%, 24.5 \%$ and $3.9 \%$ for flowers, respectively.

The cytotoxic activity of the essential oils was observed only in melanoma cultures (HT144); cultures treated for $48 \mathrm{~h}$ with EOs leaves and flowers $\left(200 \mu \mathrm{g} \cdot \mathrm{mL}^{-1}\right)$ reduced the viability by $40 \%$ and $25 \%$, respectively.

\section{Acknowledgements}

The authors thank the Conselho Nacional de Desenvolvimento Científico e Tecnológico (CNPq), the Coorde- 
nação de Aperfeiçoamento de Pessoal de Nível Superior (CAPES) and the Fundação de Amparo à Pesquisa do Estado de Minas Gerais (FAPEMIG) for financial support, a scholarship and a PVNS fellowship (D.L. Nelson).

\section{References}

[1] Cragg, G.M. and Newman, D.J. (2005) Plants as a Source of Anti-Cancer Agents. Journal of Ethnopharmacology, 100, 72-79. http://dx.doi.org/10.1016/j.jep.2005.05.011

[2] Torre, L.A., Bray, F., Siegel, R.L., Ferlay, J., Lortet-Tieulent, J. and Jemal, A. (2015) Global Cancer Statistics, 2012. CA: A Cancer Journal for Clinicians, 65, 87-108. http://dx.doi.org/10.3322/caac.21262

[3] Instituto Nacional de Câncer (INCA) José Alencar Gomes da Silva (Brasil) Disponível em: http://www.inca.gov.bracesso

[4] Gomes, M.S., Cardoso, M.G., Soares, M.J., Batista, L.R., Machado, S.M.F., Andrade, M.A., Azeredo, C.M.O., Resende, J.M.V. and Rodrigues, L.M.A. (2014) Use of Essential Oils of the Genus Citrus as Biocidal Agents. American Journal of Plant Sciences, 5, 299-305. http://dx.doi.org/10.4236/ajps.2014.53041

[5] Silva, L.F., Cardoso, M.G., Batista, L.R., Gomes, M.S., Rodrigues, L.M.A., Carvalho, D.A.S.R., Teixeira, M.L., Carvalho, M.S.S., Santiago, J.A. and Nelson, D.L. (2015) Chemical Characterization, Antibacterial and Antioxidant Activities of Essential Oils of Mentha viridis L. and Mentha pulegium L. (L). American Journal of Plant Sciences, 6, 666675. http://dx.doi.org/10.4236/ajps.2015.65072

[6] Teixeira, M.L., Cardoso, M.G., Figueiredo, A.C.S., Moraes, J.C., Assis, F.A., Andrade, J., Nelson, D.L., Souza, M.G., Souza, J.A. and Albuquerque, L.R.M. (2014) Essential Oils from Lippia origanoides Kunth. and Mentha spicata L.: Chemical Composition, Insecticidal and Antioxidant Activities. American Journal of Plant Sciences, 5, 1181-1190. http://dx.doi.org/10.4236/ajps.2014.59131

[7] BRASIL. Agência Nacional De Vigilância Sanitária. Farmacopeia brasileira. 5th Edition, Brasília, 198-199, 2010.

[8] Oliveira, C.M., Cardoso, M.G., Carvalho, M.L.M., Figueiredo, A.C.S., Miranda, C.A.S.F., Albuquerque, L.R.M., Nelson, D.L., Gomes, M.S., Silva, L.F., Santiago, J.A., Teixeira, M.L. and Brandão, R.M. (2014) Chemical Composition and Allelopathic Activity of the Essential Oil from Callistemon viminalis (Myrtaceae) Blossoms on Lettuce (Lactuca sativa L.) Seedlings. American Journal of Plant Sciences, 5, 3551-3557. http://dx.doi.org/10.4236/ajps.2014.524371

[9] Pimentel, F.A., Cardoso, M.G., Salgado, A.P.S.P., Aguiar, P.M., Silva, V.F., Morais, A.R. and Nelson, D.L. (2006) A Convenient Method for the Determination of Moisture in Aromatic Plants. Química Nova, 29, 373-375. http://dx.doi.org/10.1590/S0100-40422006000200031

[10] Adams, R.P. (2007) Identification of Essential Oils Components by Gas Chromatografhy/Mass Spectroscop. 4th Edition, Allured, Carol Streem, $804 \mathrm{p}$.

[11] Barltrop, J.A., Owen, T.C., Cory, A.H. and Cory, J.G. (1991) 5-(3-Carboxymethoxyphenyl)-2-(4,5-dime-thylthiazolyl)3-(4-sulfophenyl)tetrazolium, Inner Salt (MTS) and Related Analogs of 3-(4,5-dimethylthia-zolyl)-2,5-diphenyltetrazolium Bromide (MTT) Reducing to Purple Water-Soluble Formazans as Cell-Viability Indicators. Bioorganic \& Medicinal Chemistry Letters, 1, 611-614.

[12] Mosmann, T. (1983) Rapid Colorimetric Assay for Cellular Growth and Survival: Application to Proliferation and Cytotoxicity Assays. Journal of Immunological Methods, 65, 55-63. http://dx.doi.org/10.1016/0022-1759(83)90303-4

[13] Brochini, C.B., Nuñez, C.V., Moreira, I.C., Roque, N.F., Chaves, M.H. and Martins, D. (1999) Identificação de componentes de óleos voláteis: Análise espectroscópica de misturas de sesquiterpenos. Química Nova, 22, 37-40. http://dx.doi.org/10.1590/S0100-40421999000100008

[14] Adio, A.M., Paul, C., Kloth, P. and König, W.A. (2004) Sesquiterpenes of the Liverwort Scapania Undulate. Phytochemistry, 65, 199-206. http://dx.doi.org/10.1016/j.phytochem.2003.10.018

[15] Oyedeji, O.O., Lawal, O.A., Shode, F.O. and Oyedeji, A.O. (2009) Chemical Composition and Antibacterial Activity of the Essential Oils of Callistemon citrinus and Callistemon viminalis from South Africa. Molecules, 14, 1990-1998. http://dx.doi.org/10.3390/molecules14061990

[16] Silva, C.J., Barbosa, L.C.A., Pinheiro, A.L. and Andrade, N.J. (2010) Chemical Composition and Antibacterial Activities from the Essential Oils of Myrtaceae Species Planted in Brazil. Química Nova, 33, 104-108. http://dx.doi.org/10.1590/S0100-40422010000100019

[17] Pires, C.H., Paula, J.A.M., Tresvenzol, L.M.F., Ferri, P.H., Paula, J.R., Fiuza, T.S. and Bara, M.T.F. (2013) Composição química e atividade antimicrobiana dos óleos essenciais das folhas e flores de Callistemon viminalis (sol. ex Gaertn.) G. Don ex. Loudon (Myrtaceae). Revista de Ciências Farmacêuticas Básica e Aplicada, 34, 597-601.

[18] Deschamps, C., Zanatta, J.L., Roawalka, L., Oliveira, M.C., Bizzo, H.R. and Alquini, Y. (2012) Densidade de tricomas glandulares e produção de óleo essencial em Mentha arvensis L., Mentha x piperita L. e Mentha cf. aquatica L. Ciência e Natura, 28, 23-34. 
[19] Masetto, M.A.M., Deschamps, C., Mógor, A.F. and Bizzo, H.R. (2011) Teor e composição do óleo essencial de inflorescências e folhas de Lavandula dentata L. em diferentes estádios de desenvolvimento floral e épocas de colheita. Revista Brasileira de Plantas Medicinais, 13, 413-421. http://dx.doi.org/10.1590/S1516-05722011000400007

[20] Gobbo-Neto, L. and Lopes, N.P. (2007) Plantas Medicinais: Fatores de influência no conteúdo de metabólitos secundários. Química Nova, 30, 374-381. http://dx.doi.org/10.1590/S0100-40422007000200026

[21] Gautam, N., Mantha, A.K. and Mittal, S. (2014) Essential Oils and Their Constituents as Anticancer Agents: A Mechanistic View. BioMed Research International, 2014, Article ID: 154106. http://dx.doi.org/10.1155/2014/154106

[22] Sobral, L.M., Sousa, L.O., Coletta, R.D., Cabral, H., Greene, L.J., Tajara, E.H., Gutkind, J.S., Curti, C. and Leopoldino, A.M. (2014) Stable SET Knockdown in Head and Neck Squamous Cell Carcinoma Promotes Cell Invasion and the Mesenchymal-Like Phenotype in Vitro, as Well as Necrosis, Cisplatin Sensitivity and Lymph Node Metastasis in Xenograft Tumor Models. Molecular Cancer, 13, 1-13. http://dx.doi.org/10.1186/1476-4598-13-32

[23] Wang, W., Li, N., Luo, M., Zu, Y. and Efferth, T. (2012) Antibacterial Activity and Anticancer Activity of Rosmarinus officinalis L. Essential Oil Compared to That of Its Main Components. Molecules, 17, 2704-2713. http://dx.doi.org/10.3390/molecules17032704

[24] Hayes, A.J., Leach, D.N., Markham, J.L. and Markovic, B. (1997) In Vitro Cytotoxicity of Australian Tea Tree Oil Using Human Cell Lines. Journal of Essential Oil Research, 9, 575-582. http://dx.doi.org/10.1080/10412905.1997.9700780

[25] Lampronti, I., Saab, A.M. and Gambari, R. (2006) Antiproliferative Activity of Essential Oils Derived from Plants Belonging to the Magnoliophyta Division. International Journal of Oncology, 29, 989-995. http://dx.doi.org/10.3892/ijo.29.4.989

[26] Hassan, S.B., Gali-Muhtasib, H., Goeransson, H. and Larsson, R. (2010) Alpha Terpineol: A Potential Anticancer Agent Which Acts through Suppressing NF- $\kappa$ B Signaling. Anticancer Research, 30, 1911-1919.

[27] Jin, K., Bak, M., Jun, M., Lim, H., Jo, W. and Jeong, W.S. (2010) $\alpha$-Pinene Triggers Oxidative Stress and Related Signaling Pathways in A549 and HepG2 Cells. Food Science and Biotechnology, 19, 1325-1332. http://dx.doi.org/10.1007/s10068-010-0189-5

[28] Fontes, J.E.N., Ferraz, R.P.C., Britto, A.C.S., Carvalho, A.A., Moraes, M.O., Pessoa, C., Costa, E.V. and Bezerra, D.P. (2013) Antitumor Effect of the Essential Oil from Leaves of Guatteria pogonopus (Annonaceae). Chemistry \& Biodiversity, 10, 722-729. http://dx.doi.org/10.1002/cbdv.201200304 